\title{
Aplikasi Penilaian Kuliah Kerja Nyata Universitas Trunojoyo Madura Menggunakan Metode Rating Scale
}

\author{
Masdar Wiyono ${ }^{1}$, Firdaus Solihin ${ }^{2}$, Sigit Susanto Putro ${ }^{3}$ \\ Program Studi Teknik Informatika, Universitas Trunojoyo Madura \\ masdarwiyono@gmail.com, fsolihin@gmail.com, sigigtida.06@gmail.com
}

\begin{abstract}
ABSTRAK
KKN (Kuliah Kerja Nyata) merupakan salah satu mata kuliah wajib Universitas di Universitas Trunojoyo Madura (UTM). Selama ini proses penilaian KKN masih menggunakan cara manual sehingga memiliki beberapa kelemahan antara lain, objektivitas dan dasar penilaian kurang terjaga serta proses penilaian butuh waktu yang lama. Karena itu, keberadaan sebuah sistem penilalian KKN yang menerapkan teknologi informasi sangat dibutuhkan. Salah satu metode yang dapat diterapkan yaitu Metode Rating Scale karena mudah dan praktis untuk menilai mahasiswa yang mengikuti kegiatan KKN yang jumlahnya banyak. Metode Rating Scale dikenal dengan Skala Bertingkat, yaitu berupa suatu daftar yang berisi tentang sifat atau ciri-ciri tingkah laku yang ingin dinilai yang sudah sesuai dengan kriteria yang mau dinilai dan dicatat secara bertingkat dimulai dari nilai terendah hingga nilai yang tertinggi. Hasil dari penelitian ini yaitu, penggunaan Metode Rating Scale pada sistem penilaian KKN UTM dapat saja mempengaruhi perubahan nilai, dan perubahan nilai itu disebabkan oleh konversi dari hasil input penilaian manual ke Rating Scale. Selain itu, berdasarkan hasil pengujian aplikasi ini layak digunakan.

Kata Kunci: Kuliah Kerja Nyata, Penilaian KKN, Rating Scale.

Comuunity Service Scoring Application in LPPM UTM Using Rating Scale Method

ABSTRACT

KKN is one of compulsory lesson in the University of Trunojoyo Madura (UTM) for some majors. The scoring of KKN still uses manual scoring which has several weaknesses such as Objectivity and basic assessment is less secure also longer time needed for scoring. So that, the existence of KKN scoring system is needed. One of method that can be implemented is Rating Scale Method because of it's easiness and efficiency to score a lot of students who enrolls KKN in a certain period of time. Rating Scale Method is known as graded scale, it's like a list which comprises character or behavior will be scored with decided criteria and recorded gradually starts from the lowest to the highest score. The Results of this research is, the use of Rating Scale Method in KKN scoring system can influence the change of scores and it's change is caused by the conversion from the manual scoring input to the Rating Scale Method. Besides, based on the testing this app is able to use properly.
\end{abstract}

Keywords: Kuliah Kerja Nyata, KKN Scoring, Rating Scale. 


\section{PENDAHULUAN}

Menurut buku panduan KKN UTM dijelaskan bahwa KKN adalah suatu bentuk pendidikan dengan cara memberikan pengalaman belajar kepada mahasiswa di tengah masyarakat diluar kampus, dan secara langsung dapat membantu masyarakat didalam pembangunan dan membantu masalah-masalah yang dihadapi [1].

Selama KKN berlangsung, banyak kegiatan yang dilakukan oleh mahasiswa mulai dari proses persiapan $\mathrm{KKN}$, pelaksanaan $\mathrm{KKN}$ hingga pengumpulan laporan akhir KKN. Setiap kegiatan yang dilakukan akan dinilai oleh Dosen Pembimbing Lapangan (DPL) dan Panitia KKN secara bertahap, mulai dari tahap persiapan, pelaksanaan hingga pelaporan. Akan tetapi, sistem penilain yang sedang berjalan saat ini masih menggunakan cara manual sehingga mempunyai beberapa kelemahan diantaranya adalah, Objektivitas dan Dasar Penilaian Kurang terjaga dan Proses penilaian butuh waktu yang lama. Salah satu upaya yang bisa dilakukan adalah dengan merancang sebuah sistem penilaian yang terkoputerisasi dan bisa dilakukan secara online, sehingga penilaian menjadi Objektiv dan Dasar Penilaian tetap terjaga serta proses penilaiannya menjadi lebih cepat.

Rating Scale merupakan salah satu metode yang bisa digunakan untuk membangun sistem penilaian. Rating Scale yaitu data yang di peroleh berupa angka atau data Kuantitatif yang ditafsirkan kedalam pengertian Kualitatif [2]. Metode Rating Scale adalah metode penilaian kinerja yang menggunakan skala untuk mengukur faktor-faktor kinerja [3]. Didalam Rating Scale penilaian didasarkan pada suatu skala tertentu dari rendah sampai tinggi [4]. Seperti skala lainnya, dalam Rating Scale responden akan memilih salah satu jawaban yang telah disediakan.
Kelebihannya yaitu Rating Scale lebih fleksibel, tidak saja untuk mengukur sikap tetapi juga bisa digunakan untuk mengukur persepsi responden terhadap fenomena lingkungan, seperti skala untuk mengukur status sosial, ekonomi, pengetahuan, kemampuan, dan lain-lain. Dalam proses penilaiannya juga memudahkan bagi Team Penilai. Team Penilai hanya tinggal memberikan tanda silang $(x)$ atau contreng $(\sqrt{ })$ pada kolom yang sesuai untuk masing-masing faktor atau karakteristik yang dinilai. Akan tetapi Werther dan Davis menjelaskan bahwa metode ini mempunyai kelemahan, salah satunya yaitu adanya kecenderungan menilai secara Subjektif [5], namun kelemahan diatasi dengan mendeskripsikan skala penilaian secara kuantitatif, yaitu berdasarkan standar nilai yang sudah di tentukan di masing-masing kriteria.

Dengan melihat permasalahan diatas, dibuatlah Aplikasi Penilaian KKN dengan menerapkan Metode Rating Scale, karena metode ini lebih sesuai untuk diterapkan dalam Penilaian KKN. Tujuannya yaitu untuk melihat bagaimana Rating Scale dapat dimanfaatkan dalam membangun sebuah program aplikasi penilaian $\mathrm{KKN}$, sehingga bisa membantu proses penilaian menjadi lebih mudah dan cepat serta mengurangi subjektifitas.

\section{METODE PENELITIAN}

\section{Metode Rating Scale}

Metode Rating Scale dikenal mampu mengolah data penilaian dari data Kuantitatif yang ditafsirkan kedalam pengertian Kualitatif [2], sehingga penilai akan memilih salah satu jawaban kualitatif yang telah disediakan. Rating Scale adalah salah satu metode yang digunakan untuk memperoleh data berupa suatu daftar yang berisi tentang sifat atau ciri-ciri 
tingkah laku yang ingin diselidiki dan dicatat secara bertingkat [4].

Pada Skala Rating Scale peneliti diminta untuk merefleksikan kesan-kesan lampau yang dimasukkan ke dalam rating, sehingga dapat memberikan cara pencatatan yang mudah dan cepat dalam meringkas hasil pengamatan. Rating Scale lebih fleksibel, selain untuk mengukur sikap, bisa juga digunakan untuk mengukur persepsi responden terhadap fenomina lingkungan, seperti skala untuk mengukur status sosial, ekonomi, pengetahuan, dan lan-lain.

Beberapa alasan [7] mengapa metode ini sering dipakai secara luas, yaitu:

a. Skala ini mudah digunakan dan mudah di pahami.

b. Motede ini juga mudah dibuat dan di modifikasi jika memang dibutuhkan. Dalam kasus ini, penilai menggunakan skala berupa angkaangka mulai dari angka yang paling tinggi hingga ke yang paling rendah, dari penilaian yang paling bagus hingga ke yang paling jelek.

Rating Scale digunakan untuk melakukan penilaian terhadap Mahasiswa KKN berdasarkan faktorfaktor tertentu. Penilai akan menilai sesuai dengan kriteria tertentu. Skala yang ditetapkan dari yang terendah sampai dengan tertinggi [8].

Selanjutnya bobot dari masingmasing kriteria tersebut digunakan untuk menilai Mahasiswa KKN. Tanggapan-tanggapan penilaian akan diberikan nilai dengan Numerik agar memungkinkan skor rata-rata dihitung dan dibandingkan hasilnya.

Tabel 1. Contoh Skala Penilaian (Rating Scale)

\begin{tabular}{|c|c|}
\hline $\begin{array}{c}\text { Skala } \\
\text { Penilaian }\end{array}$ & Keterangan \\
\hline 1 & Tidak memuaskan / sangat jelek \\
\hline 2 & Perlu perbaikan / jelek \\
\hline 3 & Memenuhi harapan / cukup \\
\hline 4 & Melebihi darapan / baik \\
\hline 5 & Luar biasa / sangat baik \\
\hline
\end{tabular}

Sumber: Waryanto dan Millifati, 2006

\section{Proses Penilaian KKN}

Algoritma dalam proses

penilaian:

a. Penentuan Kriteria dan SubKriteria penilaian KKN.

b. Penentuan Bobot setiap Kriteria penilaian KKN.

c. Penentuan Skala pengukuran untuk setiap Kriteria penilaian KKN.

d. Penentuan Nilai disetiap Kriteria penilaian KKN.

e. Mengalikan Bobot Kriteria dengan nilai disetiap Kriteria.

Skor $=$ Bobot $x$ Nilai

f. Menghitung nilai yang sudah didapatkan dari setiap kriteria dengan menggunakan rumus :

Nilai KKN $=\sum_{i=1}^{n}$ Nilai Kriteria $i$ x Bobot Kriteria

Berikut Kriteria dan contoh penentuan nilai berdasarkan survey yang dilakukan di LPPM UTM dan bisa berubah sesuai kebijakan LPPM, dapat dilihat pada tabel 1:

Tabel 2. Kriteria dan Pembobotan Penilaian KKN

\begin{tabular}{|c|c|c|c|c|c|}
\hline \multicolumn{2}{|c|}{ KRITERIA PENILAIAN } & \multirow{2}{*}{$\begin{array}{l}\text { Kel/ } \\
\text { Ind }\end{array}$} & \multicolumn{3}{|c|}{ PROSENTASE } \\
\hline \multirow[t]{11}{*}{ A. } & PERSIAPAN & & & & $20 \%$ \\
\hline & $\begin{array}{l}\text { Pembekalan (Diisi } \\
\text { oleh panitia KKN) }\end{array}$ & & & $75 \%$ & \\
\hline & - Kehadiran & Ind & & & \\
\hline & - Sikap & Ind & $70 \%$ & & \\
\hline & - Keaktifan & Ind & $30 \%$ & & \\
\hline & $\begin{array}{l}\text { Usulan Rencana } \\
\text { Kegiatan/ } \\
\text { Program (Diisi } \\
\text { oleh DPL) }\end{array}$ & & & $25 \%$ & \\
\hline & $\begin{array}{l}\text { - Observasi } \\
\text { Lapangan/FGD }\end{array}$ & Ind & $20 \%$ & & \\
\hline & - Sitematika & $\mathrm{Kel}$ & $20 \%$ & & \\
\hline & $\begin{array}{l}\text { - Substansi } \\
\text { Program }\end{array}$ & Kel & $20 \%$ & & \\
\hline & $\begin{array}{l}\text { - Kelengkapan } \\
\text { Lampiran }\end{array}$ & Kel & $10 \%$ & & \\
\hline & $\begin{array}{l}\text { - Sikap dan } \\
\text { Keaktifan dalam } \\
\text { FGD }\end{array}$ & Ind & $30 \%$ & & \\
\hline \multirow[t]{5}{*}{ B. } & PELAKSANAAN & & & & $55 \%$ \\
\hline & $\begin{array}{l}\text { Kelompok (Diisi } \\
\text { oleh DPL) }\end{array}$ & & & $30 \%$ & \\
\hline & $\begin{array}{l}\text { - Pelaksanaan } \\
\text { Program Kerja } \\
\text { (kesesuaian } \\
\text { dengan jadwal) }\end{array}$ & Kel & $30 \%$ & & \\
\hline & $\begin{array}{l}\text { - Partisipasi } \\
\text { masyarakat }\end{array}$ & Kel & $40 \%$ & & \\
\hline & $\begin{array}{l}\text { - Tertib } \\
\text { Administrasi }\end{array}$ & Kel & $30 \%$ & & \\
\hline
\end{tabular}




\begin{tabular}{|c|c|c|c|c|c|}
\hline \multicolumn{2}{|c|}{ KRITERIA PENILAIAN } & \multirow[t]{2}{*}{$\begin{array}{l}\text { Kel/ } \\
\text { Ind }\end{array}$} & \multicolumn{3}{|c|}{ PROSENTASE } \\
\hline & $\begin{array}{l}\text { + Usulan } \\
\text { Program (cetak, } \\
\text { bukan dalam file } \\
\text { komputer) }\end{array}$ & & & & \\
\hline & $\begin{array}{l}\text { + Daftar hadir } \\
\text { peserta program, } \\
\text { Log Book }\end{array}$ & & & & \\
\hline & $\begin{array}{l}\text { + Realisasi } \\
\text { pelaksanaan } \\
\text { program kerja } \\
\text { (ditempel) }\end{array}$ & & & & \\
\hline & $\begin{array}{l}\text { + Buku Tamu (per } \\
\text { kelompok desa) }\end{array}$ & & & & \\
\hline & + Web/Blog Desa & & & & \\
\hline & $\begin{array}{l}\text { Individu (Diisi } \\
\text { oleh DPL) }\end{array}$ & & & $70 \%$ & \\
\hline & - Kehadiran & Ind & & & \\
\hline & $\begin{array}{l}\text { - Kerjasama dalam } \\
\text { Tim }\end{array}$ & Ind & $20 \%$ & & \\
\hline & $\begin{array}{l}\text { - Sikap, perilaku, } \\
\text { dan keaktifan }\end{array}$ & Ind & $60 \%$ & & \\
\hline & $\begin{array}{l}\text { - Log Book } \\
\text { Mahasiswa }\end{array}$ & Ind & $20 \%$ & & \\
\hline C. & LAPORAN AKHIR & & & & $25 \%$ \\
\hline & $\begin{array}{l}\text { Laporan (Diisi } \\
\text { oleh DPL) }\end{array}$ & & & $50 \%$ & \\
\hline & $\begin{array}{l}\text { - Sistematika dan } \\
\text { Kelengkapan }\end{array}$ & $\mathrm{Kel}$ & $40 \%$ & & \\
\hline & $\begin{array}{l}\text { - ketepatan waktu } \\
\text { pengumpulan }\end{array}$ & Kel & $60 \%$ & & \\
\hline & $\begin{array}{l}\text { Produk KKN (Diisi } \\
\text { oleh Panitia KKN) }\end{array}$ & & & $50 \%$ & \\
\hline & - Pameran & Kel & $40 \%$ & & \\
\hline & $\begin{array}{l}\text { - Web + Video } \\
\text { Profil }\end{array}$ & Kel & $30 \%$ & & \\
\hline & - Buku Desa & Kel & $30 \%$ & & \\
\hline
\end{tabular}

\section{Rancangan Sistem}

\section{a. Use Case Diagram}

Use Case Diagram adalah alat yang digunakan untuk mengidentifikasi dan menggambarkan keseluruhan proses bisnis yang mempengaruhi sistem [8].

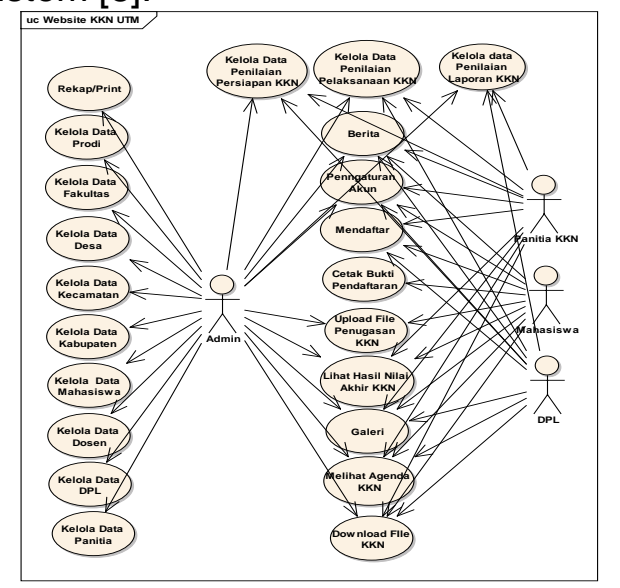

Gambar 1. Use Case Diagram Penilaian
Use Case Diagram pada gambar 1 merupakan use case diagram yang dirancang berdasarkan kebutuhan sistem dalam proses penilaian KKN di LPPM Universitas Trunojoyo Madura. Proses penilaian KKN ini melibatkan pegawai LPPM sebagai Panitia KKN, Dosen Pembimbing Lapangan (DPL) serta Mahasiswa yang mengikuti kegiatan KKN.

\section{b. Activity Diagram}

1. Penilaian Pembekalan KKN

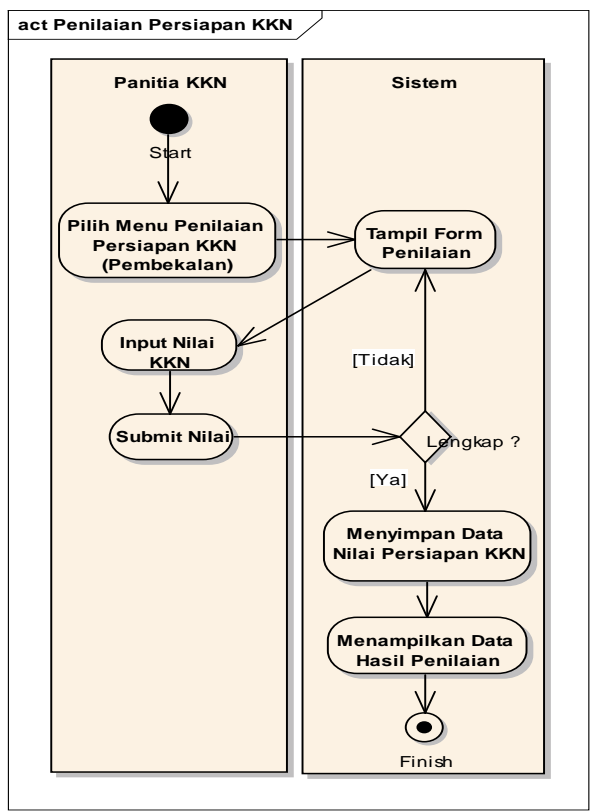

Gambar 2. Penilaian Pembekalan KKN

Gambar 2. di atas merupakan diagram aktivitas penilaian pembekalan KKN. Penilaian ini dilakukan oleh Panitia KKN. Dimulai setelah user melakukan login, lalu dilanjutkan dengan memilih Menu Penilaian Persiapan KKN yang didalamnya terdapat menu tahap penilaian Pembekalan. Selanjutnya user akan menilai Pembekalan KKN. Kemudian user menekan tombol Submit Nilai. Jika nilai belum lengkap, maka sistem akan mengembalikan ke Form Penilaian, jika sudah lengkap, maka data nilai akan disimpan oleh sistem dan nilai yang sudah tersimpan akan ditampilkan ke user. 
2. Penilaian Usulan Program KKN

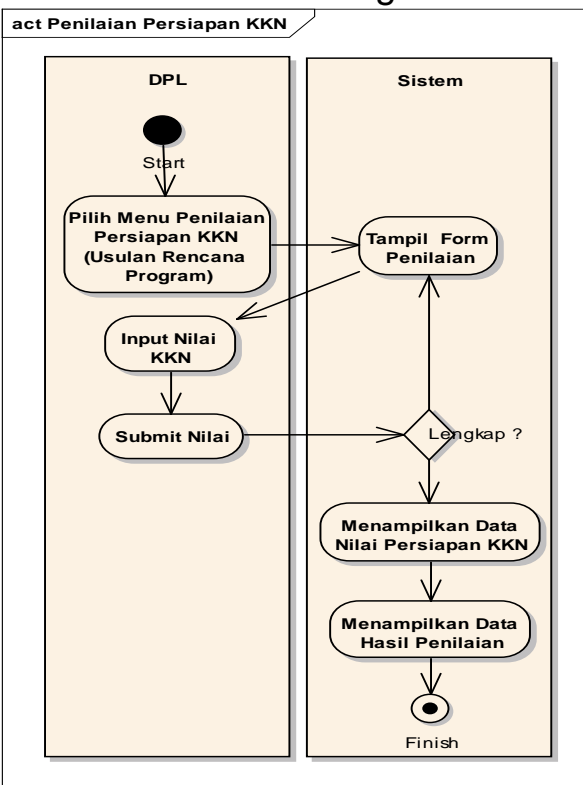

Gambar 3. Penilaian Usulan Program

Gambar 3. adalah activity diagram menggambarkan aktivitas user terhadap sistem dalam melakukan Penilaian Usulan Program. Penilaian dilakukan oleh DPL. Dimulai setelah user melakukan login, lalu dilanjutkan dengan memilih Menu Penilaian Persiapan KKN yang didalamnya terdapat menu tahap penilaian Usulan Rencana Program. Selanjutnya user mengisi Nilai KKN. Kemudian user menekan Tombol Submit Nilai, jika nilai belum lengkap, maka sistem akan mengembalikan ke Form Penilaian Usulan Program dan jika sudah lengkap, maka data nilai akan tersimpan. Nilai yang sudah tersimpan akan ditampilkan ke user.

\section{Penilaian Pelaksanaan KKN}

Gambar 4. merupakan activity diagram penilaian Pelaksanaan KKN. Penilaian ini dilakukan oleh DPL disetiap kelompok KKN. Proses Penilaian dimulai setelah user melakukan login, lalu dilanjutkan dengan memilih Menu Penilaian Pelaksanaan KKN yang didalamnya terdapat menu penilaian Individu dan Penilaian Kelompok. Setelah user memilih salah satu menu, maka sistem akan menampilkan Form Penilaian sesuai dengan menu yang dipilih oleh user. Selanjutnya user akan mengisi Nilai KKN kemudian tekan Tombol Submit Nilai. Jika nilai belum lengkap, maka sistem akan mengembalikan ke Form Penilaian, jika sudah lengkap, maka data nilai akan disimpan oleh sistem dan nilai yang sudah tersimpan akan ditampilkan ke user.

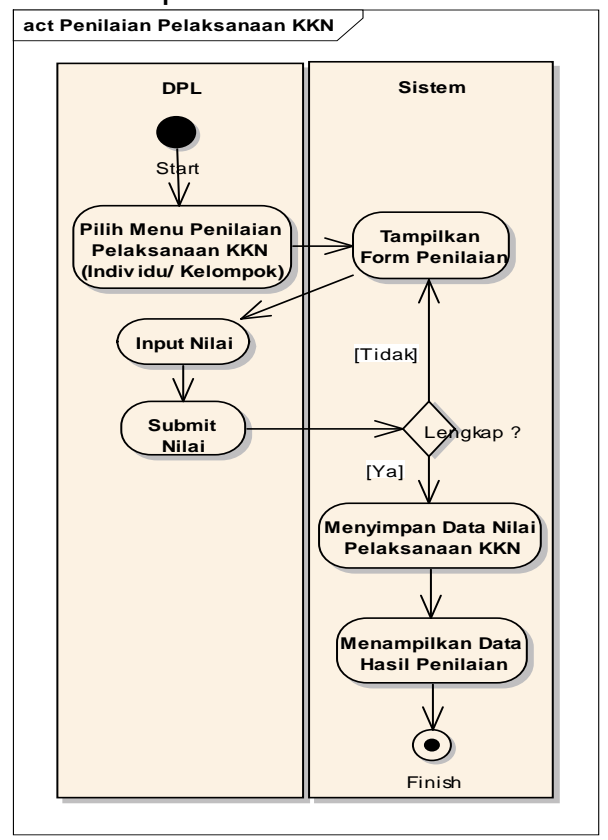

Gambar 4. Penilaian Pelaksanaan KKN

4. Nilai Pelaporan Akhir KKN

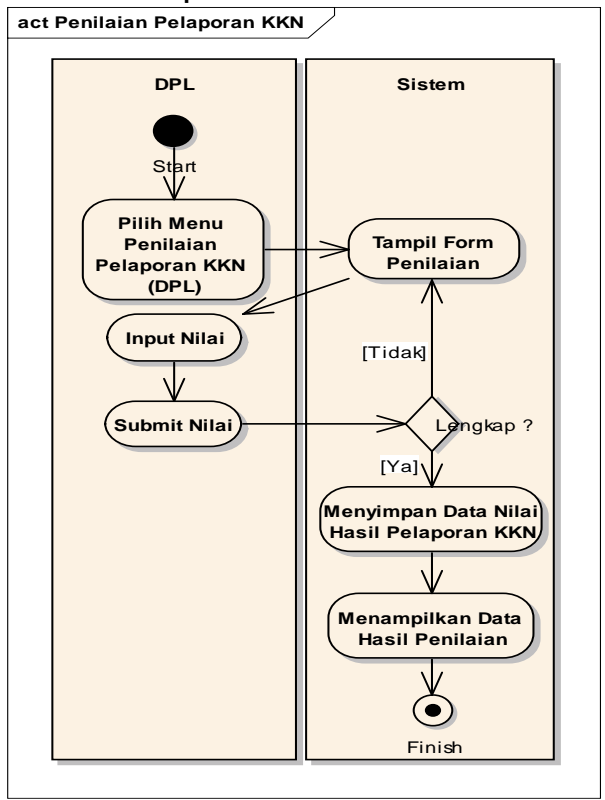

Gambar 5. Penilaian Pelaporan KKN 
gambar 5. menggambarkan aktivitas penilaian terhadap Laporan KKN yang dilaksanakan oleh DPL. Proses penilaian dilakukan oleh user setelah login dan berhasil masuk ke sistem, maka selanjutnya user memilih Menu Penilaian Pelaporan KKN. Selanjutnya user akan mengisi Nilai KKN kemudian menekan tombol Submit, jika nilai belum lengkap, maka sistem akan mengembalikan ke Form Penilaian. Jika sudah lengkap, maka data disimpan dan nilai yang sudah tersimpan akan ditampilkan ke user.

\section{Penilaian Produk KKN}

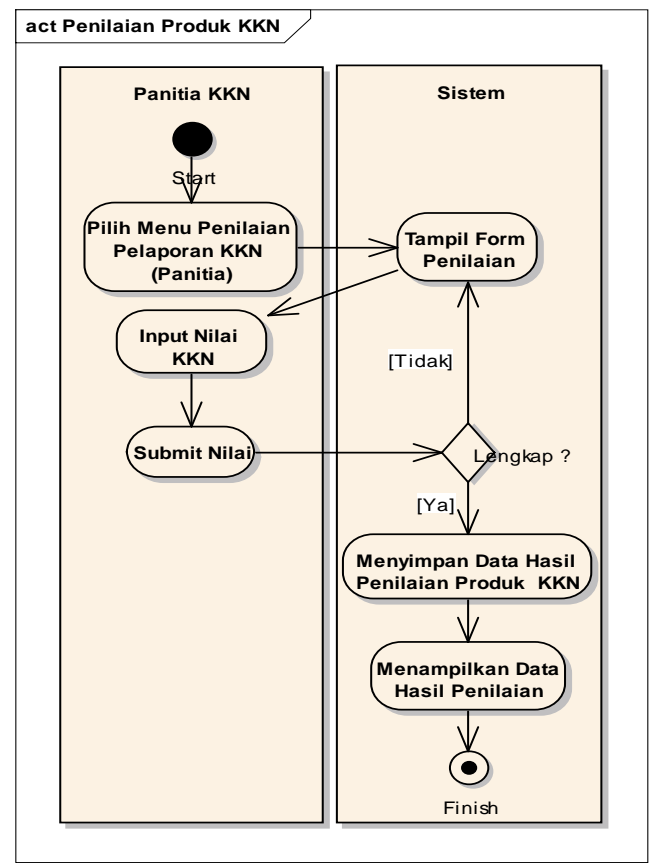

Gambar 6. Penilaian Produk KKN

Gambar 6. adalah gambar diagram aktifitas penilaian Produk KKN yang dilakukan oleh Panitia KKN. Proses penilaian dilakukan dengan cara user Login ke sistem, setelah berhasil, maka dilanjutkan memilih Menu Penilaian Produk KKN. Setelah user memilih salah satu menu diantaranya adalah (Web Desa, Video Profile, Buku Desa dan Pameran Produk KKN). Selanjutnya user akan mengisi Nilai KKN kemudian tekan Tombol Submit. Jika nilai belum lengkap, maka sistem akan mengembalikan ke Form Penilaian, jika sudah lengkap data disimpan dan nilai yang sudah tersimpan akan ditampilkan ke user.

\section{c. Arsitektur Diagram}

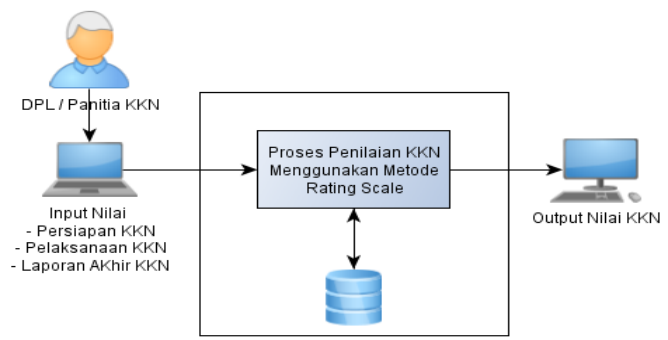

Gambar 7. Arsitektur Diagram Sistem Penilaian KKN

Penilaian KKN berbasis website dengan cara menyediakan Form penilaian di masing-masing kegiatan yang akan dinilai dalam bentuk Web. Nilai yang diinputkan bisa langsung terkirim pada saat DPL/Panitia mengirim hasil penilaiannya. Kemudian data penilaian yang sudah terseimpan akan di proses oleh sistem menggunakan Metode Rating Scale. Output yang dihasilkan yaitu nilai akhir KKN berupa nilai angka dan nilai huruf dari masing-masing mahasiswa yang dinilai.

\section{HASIL DAN PEMBAHASAN}

\section{Hasil Implementasi Sistem}

Tujuan dibangunnya sistem ini yaitu untuk membangun sistem Penilaian KKN di LPPM Universitas Trunojoyo Madura dengan menerapkan Metode Rating Scale.

a. Tampilan Halaman Penilaian Pembekalan

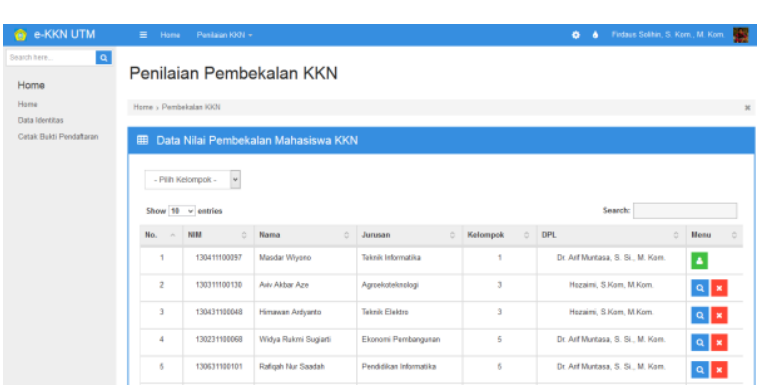

Gambar 8. Tampilan Halaman Penilaian Pembekalan 
Gambar 8 merupakan antarmuka penilaian pembekalan KKN. Data yang ditampilkan yaitu NIM, nama, jurusan, kelompok dan DPL dari setiap kelompok. Di halaman ini ditampilkan semua mahasiswa KKN pada periode terakhir. Ada tiga menu dalam tampilan ini, yaitu menu input berfungsi ketika Panitia ingin menginputkan nilai. Menu detail berfungsi untuk melihat data detail hasil penilaian yang sudah terinput dan menu hapus berfungsi untuk menghapus data hasil penilaian. Untuk tampilan halaman penilaian yang lain formnya hampir sama, yang membedakan hanya Kriteria.

b. Tampilan Halaman Input Nilai Pembekalan

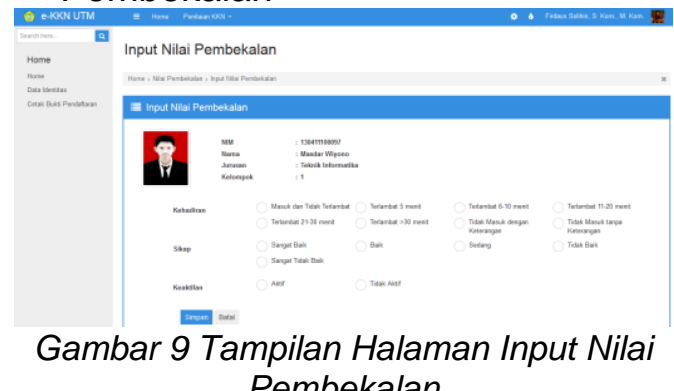

Gambar 9 merupakan halaman input nilai pembekalan. Kriteria yang harus diinputkan nilainya yaitu Kehadiran, sikap dan keaktifan. Dalam penginputan nilai tersebut menggunakan Rating Scale, yaitu berupa suatu daftar yang berisi tentang sifat atau ciri-ciri tingkah laku yang ingin dinilai yang sudah sesuai dengan kriteria yang mau dinilai dan dicatat secara bertingkat dimulai dari nilai terendah hingga nilai yang tertinggi. Selain itu ada dua menu dalam tampilan di atas, yaitu menu Simpan berfungsi untuk menyimpan nilai hasil inputan. Menu Batal berfungsi untuk membatalkan proses penilaian. Untuk form yang lain tampilannya hamper sama, namun perbedaannya pada keiteria penilaian.
c. Tampilan Halaman Detail Nilai pembekalan

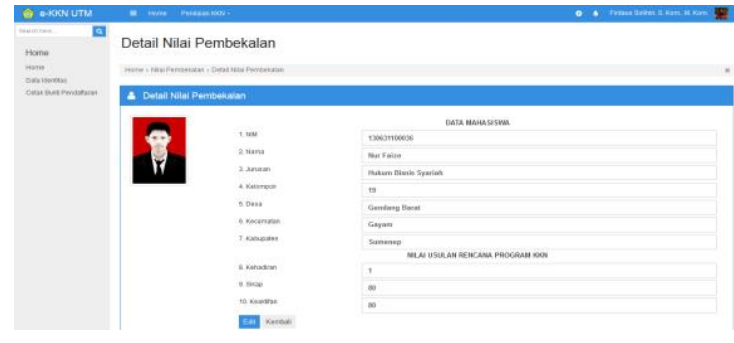

Gambar 10 Tampilan Halaman Detail Nilai Pembekalan

Gambar 10 menampilkan detail nilai Pembekalan. Data yang di tampilkan yaitu Foto, NIM, Nama, Jurusan, Kelompok, Desa, Kecamatan, Kabupaten dan nilai Pembekalan yang terdiri dari Kehadiran, Sikap dan Keaktifan. Di halaman tersebut juga terdapat menu edit yang berfungsi untuk mengedit nilai. Untuk form detail yang lain hampir sama, namun perdedaannya terletak pada kriteria penilaian.

d. Tampilan Halaman Edit Nilai Pembekalan

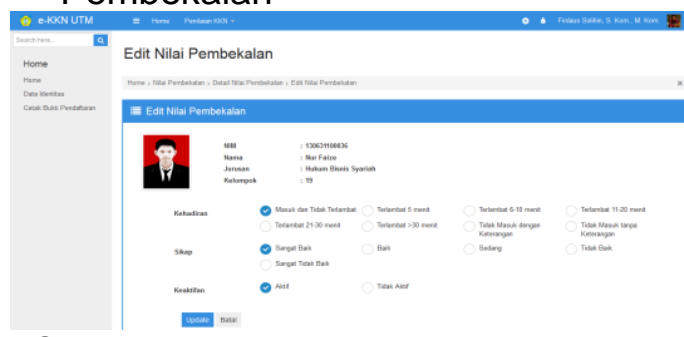

Gambar 11. Tampilan Halaman Edit Nilai Pembekalan

$\begin{array}{lll}\text { Gambar } 11 & \text { merupakan } \\ \text { tampilan halaman edit nilai }\end{array}$

Pembekalan. Data yang akan di edit adalah Kehadiran, Sikap dan Keaktifan. Untuk form Edit yang lain hampir sama, namun perdedaannya terletak pada kriteria penilaian.

e. Tampilan Hasil Penilaian KKN

Gambar 12 merupakan tampilan hasil penilaian pada halaman Admin. Data yang ditampilkan yaitu NIM, nama, jurusan, kelompok, desa, kecamatan, kabupaten, DPL dan Nilai Akhir. Ada satu menu detail digunakan untuk melihat data detail hasil penilaian baik yang sudah terinput maupun yang belum terinput. 


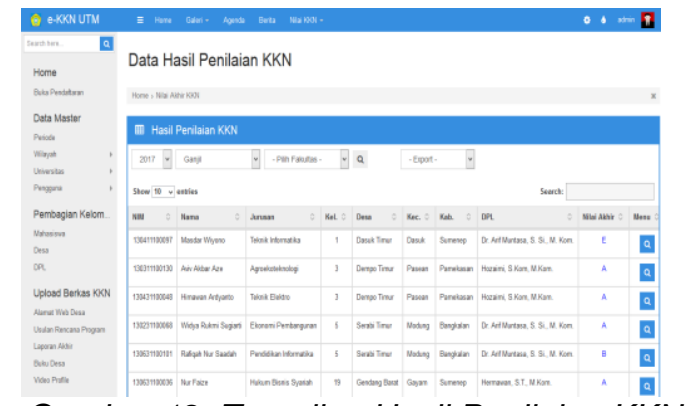

Gambar 12. Tampilan Hasil Penilaian KKN

f. Hasil perbandingan penilaian KKN

Hasil perbandingan penilaian KKN yang dilakukan secara manual kemudian dibandingkan dengan hasil penilaian yang dilakukan oleh sistem dengan Metode Rating Scale dapat diketahui bahwa, metode Rating Scale bisa digunakan dalam sistem penilaian KKN. Berdasarkan data mahasiswa yang berjumlah 109, dari data hasil perhitungan ada 3 data mahasiswa yang nilainya mengalami perubahan dengan rata-rata selisih $\mathbf{2 . 4 4 6 1}$. Sedangkan margin errornya dapat dihitung yaitu $(3 / 109) * 100 \%=3 \%$. Sedangkan yang menyebabkan nilai itu berubah diakibatkan oleh konversi nilai manual ke Rating Scale.

\section{PENGUJIAN}

Pengujian sistem pada penelitian ini terdiri dari 4 aspek, yaitu aspek fungsionality, reliability, efficiency dan portability.

\section{a. Pengujian Fungsionality}

dilakukan dengan cara

memperkenalkan dan cara penggunaannya kepada seluruh stakeholder yang berperan dalam kegiatan KKN UTM seperti Admin, Panitia, Dosen Pembimbing Lapangan (DPL), Mahasiswa yang mengikuti KKN dan Masyarakat Kampus UTM. Kemudian dilakukan pengisian angket oleh masing-masing stakeholder. Instrumen angket yang digunakan dalam tahapan pengujian terhadap aplikasi berdasarkan pada funsionalitas sistem.
Dari hasil jawaban responden kemudian dilakukan penghitungan untuk menentukan presentase dari hasil pengujian. Penghitungan dilakukan mengunakan rumus dari ISO/IEC 9126 sebagai berikut :

Keterangan :

$$
\mathrm{X}=1-\frac{A}{B}
$$

$X=$ Tingkat functionality.

$A=$ Jumlah fungsi yang bermasalah .

$B=$ Jumlah fungsi yang diuji keseluruhan.

Sehingga :

$$
X=1-\frac{0}{439}=1-0=1
$$

Berdasarkan hasil pengujian functionality yang didapatkan sebesar 1. Untuk dapat memenuhi standar functionality, diperlukan tingkat functionality yang mendekati atau bernilai 1. Sehingga dari hasil pengujian tersebut maka Sistem Penilaian Kuliah Kerja Nyata LPPM UTM menggunakan Metode Rating Scale telah memenuhi standar untuk karakteristik functionality menurut ISO/IEC 9126.

\section{b. Pengujian Reliability}

Karakteristik reliability dilakukan dengan pengujian terhadap kriteria Session, Pages dan Hits dengan menggunakan tools WAPT (Web Application Performance Tools),

\begin{tabular}{lccc}
\multicolumn{4}{c}{ Tabel 3. Hasil Pengujian Reliability } \\
\hline \multicolumn{1}{c}{ Kriteria } & Berhasil & Gagal & Total \\
\hline Sessions & 0 & 0 & 0 \\
Pages & 7 & 0 & 7 \\
Hits & 60 & 6 & 60 \\
\hline
\end{tabular}

Tabel 3 adalah hasil pengujian Aplikasi WAPT. Dari tabel tersebut terdapat kriteria dari yang diuji, ada 3 kriteria, yaitu Sessions, Pages dan Hits. Kolom berhasil, berisi jumlah nilai keberhasilan pengujian tiap kriteria. Selain itu ada kolom Gagal, berisi jumlah nilai pengujian yang di setiap kriteria. Kolom total berisi jumlah nilai total dimasing-masing kriteria. 
Untuk mengetahui hasilnya dihitung menggunakan persamaan berikut :

$$
X=\frac{A}{B} \times 100 \%
$$

Keterangan :

$X=$ Nilai reliability.

$A=$ Jumlah berhasil dalam pengujian.

$\mathrm{B}=$ Jumlah pengujian keseluruhan

Sehingga

Sessions : $X=\frac{0}{0} \times 100 \%=100 \%$

Pages $: X=\frac{7}{7} \times 100 \%=100 \%$

Hits $: X=\frac{60}{60} \times 100 \%=100 \%$

Berdasarkan hasil pengujian reliability, didapatkan nilai Sessions, Pages, dan Hits sebesar $100 \%$. Menurut teori Telcordia menyatakan jika hasil pengujian yang sukses $\geq 95 \%$ dikatakan memenuhi aspek reliability, sehingga dapat disimpulkan bahwa Sistem Penilaian Kuliah Kerja Nyata LPPM UTM menggunakan Metode Rating Scale telah memenuhi standar kualitas aspek reliability.

\section{a. Pengujian Efficiency}

Hasil pengujian aspek efficiency Sistem Penilaian Kuliah Kerja Nyata ini sebagai berikut:

Tabel 4. Hasil Pengujian Aspek Efficiency

\begin{tabular}{|c|c|c|c|c|c|c|}
\hline No. & Halaman & $\begin{array}{c}\text { Total } \\
\text { Weight } \\
\text { (KB) }\end{array}$ & $\begin{array}{l}\text { Jml } \\
\text { HTTP } \\
\text { lequest }\end{array}$ & Skor & Grade & $\begin{array}{l}\text { Load Time } \\
\quad(\mathrm{ms})\end{array}$ \\
\hline 1 & Website & 1938,3 & 22 & 72 & C & 3633 \\
\hline 2 & Login & 1938,3 & 22 & 79 & C & 1794 \\
\hline 3 & $\begin{array}{l}\text { Data Nilai } \\
\text { Pembekalan }\end{array}$ & 1938,3 & 22 & 75 & C & 3718 \\
\hline 4 & $\begin{array}{l}\text { Input Nilai } \\
\text { Pembekalan }\end{array}$ & 1938,3 & 22 & 75 & C & 1354 \\
\hline 5 & $\begin{array}{l}\text { Data Nilai Usulaı } \\
\text { Program Kelomp }\end{array}$ & 1938,3 & 22 & 75 & C & 999 \\
\hline 6 & $\begin{array}{l}\text { Input Nilai Usula } \\
\text { Program Kelomp }\end{array}$ & 1938,3 & 22 & 75 & C & 1994 \\
\hline 7 & $\begin{array}{l}\text { Data Nilai Usulaı } \\
\text { Program Individı }\end{array}$ & 1938,3 & 22 & 75 & C & 2762 \\
\hline 8 & $\begin{array}{l}\text { Input Nilai Usula } \\
\text { Program Individı } \\
\text { Data Nilai }\end{array}$ & 1938,3 & 22 & 75 & C & 2042 \\
\hline 9 & $\begin{array}{l}\text { Pelaksanaan } \\
\text { Kelompok } \\
\text { Input Nilai }\end{array}$ & 1938,3 & 22 & 75 & C & 4283 \\
\hline 11 & $\begin{array}{l}\text { Pelaksanaan } \\
\text { Individu }\end{array}$ & 1938,3 & 22 & 75 & C & 6691 \\
\hline
\end{tabular}

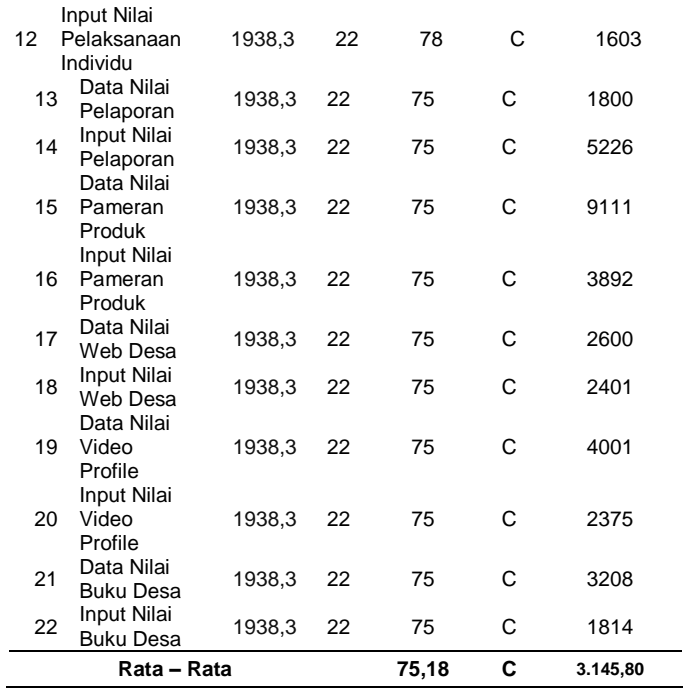

Berdasarkan hasil pengujian aspek efficiency menggunakan YSlow dan Page Speed Monitor, secara keseluruhan diperoleh hasil pengujian Sistem Penilaian Kuliah Kerja Nyata LPPM UTM seperti ditunjukkan oleh Tabel 4.136. Sehingga dapat disimpulkan Sistem Penilaian ini memiliki skor rata-rata $\mathbf{7 5 , 1 8}$ dan memiliki Grade C. Rata-rata waktu yang dibutuhkan untuk memuat tiap halaman (Load Time) adalah 3.145,8 ms, sehingga berdasarakan hasil ratarata waktu maka dapat disimpulkan bahwa load time berada dalam ambang dimana user masih bisa fokus terhadap halaman web [10].

\section{b. Pengujian Portability}

Pengujian Portability menggunakan 4 jenis web browser berbasis desktop diantaranya adalah Mozilla Firefox, Google Chrome, Safari dan Opera. Hasil dari pengujian portabilty pada keempat web browser adalah sebagai berikut :

Tabel 5. Hasil Pengujian Portability

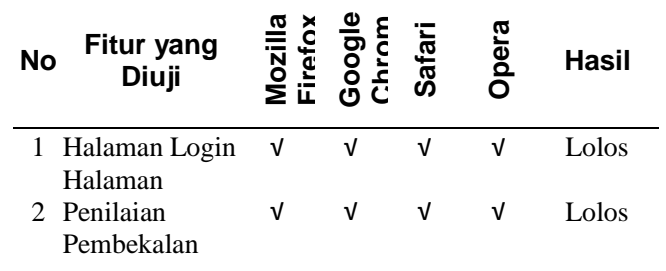




\begin{tabular}{|c|c|c|c|c|c|c|}
\hline No & $\begin{array}{c}\text { Fitur yang } \\
\text { Diuji }\end{array}$ & 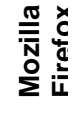 & 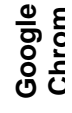 & ल & 잉 & Hasil \\
\hline & Halaman Input & & & & & \\
\hline 3 & $\begin{array}{l}\text { Nilai } \\
\text { Pembekalan } \\
\text { Halaman }\end{array}$ & v & $v$ & $\mathrm{v}$ & $v$ & Lolos \\
\hline 4 & $\begin{array}{l}\text { Penilaian } \\
\text { Usulan } \\
\text { Program } \\
\text { Halaman Input }\end{array}$ & v & $v$ & $\mathrm{v}$ & $v$ & Lolos \\
\hline 5 & $\begin{array}{l}\text { Nilai Usulan } \\
\text { Program } \\
\text { Halaman }\end{array}$ & v & $v$ & $v$ & $v$ & Lolos \\
\hline 6 & $\begin{array}{l}\text { Penilaian } \\
\text { Pelaksanaan } \\
\text { Halaman Input }\end{array}$ & v & V & $\mathrm{v}$ & V & Lolos \\
\hline 7 & $\begin{array}{l}\text { Nilai } \\
\text { Pelaksanaan } \\
\text { Halaman }\end{array}$ & v & $v$ & $\mathrm{v}$ & $v$ & Lolos \\
\hline 8 & $\begin{array}{l}\text { Penilaian } \\
\text { Pelaporan }\end{array}$ & v & V & $\mathrm{v}$ & V & Lolos \\
\hline 9 & $\begin{array}{l}\text { Halaman Input } \\
\text { Nilai Pelaporan } \\
\text { Halaman }\end{array}$ & v & V & $\mathrm{V}$ & $v$ & Lolos \\
\hline 10 & $\begin{array}{l}\text { Penilaian } \\
\text { Pameran } \\
\text { Produk } \\
\text { Halaman Input }\end{array}$ & v & $v$ & $\mathrm{~V}$ & $v$ & Lolos \\
\hline 11 & $\begin{array}{l}\text { Nilai Pameran } \\
\text { Produk } \\
\text { Halaman }\end{array}$ & $v$ & v & V & V & Lolos \\
\hline 12 & $\begin{array}{l}\text { Penilaian Web } \\
\text { Desa }\end{array}$ & $v$ & $\checkmark$ & $v$ & $v$ & Lolos \\
\hline 13 & $\begin{array}{l}\text { Halaman Input } \\
\text { Nilai Web Desa } \\
\text { Halaman }\end{array}$ & v & v & V & V & Lolos \\
\hline 14 & $\begin{array}{l}\text { Penilaian Video } \\
\text { Profil } \\
\text { Halaman Input }\end{array}$ & $v$ & V & V & V & Lolos \\
\hline 15 & $\begin{array}{l}\text { Nilai Video } \\
\text { Profil } \\
\text { Halaman }\end{array}$ & $v$ & $\checkmark$ & $v$ & $\checkmark$ & Lolos \\
\hline 16 & $\begin{array}{l}\text { Penilaian Buku } \\
\text { Desa } \\
\text { Halaman Input }\end{array}$ & $v$ & $\checkmark$ & $v$ & $\checkmark$ & Lolos \\
\hline 17 & $\begin{array}{ll}\text { Nilai } & \text { Buku } \\
\text { Desa } & \\
\text { Halaman } & \text { Data }\end{array}$ & $v$ & V & $v$ & $v$ & Lolos \\
\hline 18 & $\begin{array}{ll}\text { Nilai Akhir } \\
\text { KKN }\end{array}$ & V & V & V & V & Lolos \\
\hline
\end{tabular}

Postability menggunakan 4 jenis web browser diantanya Mozilla Firefox, Google Chrome, Safari dan Opera semua tampilan dinyatakan Lolos uji coba Portability. Hal ini berdasar pada pendapat Schach [9], yaitu aplikasi berbasis web dikatakan memenuhi aspek portability jika dapat dibaca pada berbagai web browser.

\section{SIMPULAN DAN REKOMENDASI}

Berdasarkan hasil penelitian yang telah dilakukan maka dapat disimpulkan sebagai berikut:

a. Dari data hasil pengujian tentang penerapan Metode Rating Scale pada Aplikasi Penilaian Kuliah Kerja Nyata LPPM UTM menunjukan adanya perbedaan nilai akhir KKN yang disebabkan oleh konversi nilai manual ke Rating Scale dari hasil perhitungan data mahasiswa yang berjumlah 109, ada 3 data mahasiswa yang nilainya mengalami perubahan, dengan rata-rata selisih 2,4461 dari semua data mahasiswa. Sedangkan margin erromya 3\%. Sehingga dapat disimpulkan bahwa penggunaan Metode Rating Scale pada Sistem Penilaian Kuliah Kerja Nyata LPPM UTM bisa saja mempengaruhi perubahan nilai, dan perubahan nilai itu disebabkan oleh konversi dari hasil input penilaian manual ke Rating Scale.

b. Pengujian tingkat kualitas Aplikasi Penilaian Kuliah Kerja Nyata LPPM UTM menggunakan standar pengujian ISO 9126. pengujian fungsionality menghasilkan nilai 1 (Baik), pengujian reliability yang mencakup session, page dan hits menghasilkan 100\% (Memenuhi), pengujian efficiency menggunakan aplikasi YSlow menghasilkan ratarata performance resource sebesar 75,18 dengan Grade C serta ratarata load time sebesar 3.145,8 detik (Diterima), dan pengujian portability menggunakan 4 web browser dapat berjalan dengan baik tanpa error, sehingga (Memenuhi). Berdasarkan hasil pengujian tersebut maka dapat disimpulkan Aplikasi Penilaian Kuliah Kerja Nyata LPPM UTM menggunakan Metode Rating Scale layak untuk digunakan. 


\section{Rekomendasi}

Beberapa aspek yang perlu dikembangkan dalam penelitian ini adalah sebagai berikut:

a. Akan lebih baik jika dalam sistem ini pembagian kelompok dilakukan oleh sistem secara otomatis tanpa harus diatur oleh admin/panitia dengan memanfaatkan metode tertentu.

\section{DAFTAR PUSTAKA}

[1] LPPM-UTM. (2016). Panduan Kuliah Kerja Nyata (KKN) Tematik Semester Genap Tahun Akademik 2015-2016, Bangkalan: Lembaga Penelitian dan Pengabdian Masyarakat Universitas Trunojoyo Madura.

[2] Windiyani, T. (2012, Desember). Instrumen untuk menjaring data interval. Nominal, ordinal dan data tentang kondisi, keadaan, hal tertentu dan data untuk menjaring variabel kepribadian, Jurnal Pendidikan Dasar, Vol.3; No.5, pp. $203-208$.

[3] Mondy, R. Wayne, and Noe, Robert M. (2005). Human Resource Management, USA: Prentice Hall.

[4] Werther, William, B., dan Davis, K. (1996). Human Resources and Personnel Management, USA: Mc Graw Hill. b. Akan lebih baik jika Database dalam sistem ini menggunakan konsep Data Warehouse, karena database terlalu besar, sehingga di khawatirkan akan mengalami error pada saat memuat data yang terlalu banyak.

[5] Panggabean, Mutiara S. (2002). Manajemen Sumberdaya Manusia, Jakarta: Ghalia Indonesia.

[7] Sulistyawan, F., Wurijanto, T., Subiyantoro, Y.Y. (2013). Sistem Informasi Penilaian Kinerja Pegawai Menggunakan Metode Graphic Rating Scales Dan 360 Derajat, Situs Jurnal Sistem Informasi STIKOM Surabaya.

[8] Suhendar, A. dan Gunadi, H. (2002). Visual Modelling Menggunakan UML dan Rational Rose, Bandung: Informatika.

[9] Schach, Stephen R. (2008). Object-Oriented Software Engineering. New York:McGrawHill Companies, Inc. 